\title{
EVALUATION OF PHYSICAL ACTIVITY, BODY MASS INDEX AND SELF-ASSESSMENT OF PHYSICAL FITNESS IN FEMALE STUDENTS AND PUPILS OF TERNOPIL, WESTERN UKRAINE
}

\section{OCENA AKTYWNOŚCI FIZYCZNEJ, WSKAŹNIKA MASY CIAŁA I SAMOOCENY SPRAWNOŚCI FIZYCZNEJ WSRÓD STUDENTEK I UCZENNIC Z TARNOPOLA, UKRAINA ZACHODNIA}

\author{
Dariya Popovych $^{1(\mathrm{~B}, \mathrm{E}, \mathrm{F})}$, Józef Bergier ${ }^{2(\mathrm{~A}, \mathrm{C}, \mathrm{E}, \mathrm{F}, \mathrm{G})}$, Mykhaylo Korda $^{1(\mathrm{D}, \mathrm{E})}$, Ivan Klishch ${ }^{1(\mathrm{E}, \mathrm{F})}$, \\ Olha Sopel ${ }^{1(C, F)}$, Lyudmila Tsybulskaya ${ }^{1(A)}$
}

${ }^{1}$ I. Horbachevsky Ternopil State Medical University, Ukraine

${ }^{2}$ Pope John Paul II State School of Higher Education in Biala Podlaska, Poland

Authors' contribution Wkład autorów:

A. Study design/planning zaplanowanie badań B. Data collection/entry zebranie danych

C. Data analysis/statistics dane - analiza i statystyki D. Data interpretation interpretacja danych E. Preparation of manuscript przygotowanie artykułu F. Literature analysis/search wyszukiwanie i analiza literatury G. Funds collection zebranie funduszy
Tables: 0

Figures: 9

References: 43

Submitted: 2017 Jul 21

Accepted: 2017 Aug 21

\section{Summary}

Background. Lifestyle is one of the key factors that determines the proper development of human body, its systems and functions. An appropriate level of physical activity and BMI are thus integral components of a healthy lifestyle.

Material and methods. The study involved 333 female students of Ternopil State Medical University and 409 schoolgirls of Ternopil, western Ukraine. The International Physical Activity Questionnaire (IPAQ-L) was used as a research method. BMI and physical activity self-assessment rates were also considered.

Results. The surveyed female students of Ternopil State Medical University and schoolgirls of Ternopil (western Ukraine) demonstrate a high level of total physical activity. Most of the surveyed female students (71.1\%) and pupils (59.4\%) had normal body weight. The schoolgirls' self-assessment of physical fitness was lower and more adequate when compared to that of female students. Besides, both students and pupils who indicated that they had no free time spent it in a more reasonable way than those who considered that they had enough of it or not enough.

Conclusions. The female students of medical university and female pupils of Ternopil are fully aware that physical activity is significant for their lives and that it constitutes a key factor to a healthy lifestyle.

Keywords: physical activity, IPAQ-L, Body Mass Index (BMI), self-assessment, physical fitness, female, student

\section{Streszczenie}

Wprowadzenie. Styl życia jest jednym z kluczowych czynników determinujących prawidłowy rozwój ludzkiego ciała, jego systemów i funkcji. Odpowiedni poziom aktywności fizycznej i BMI są zatem integralnymi składnikami zdrowego stylu życia.

Materiał i metody. W badaniu wzięło udział 333 studentek Państwowego Uniwersytetu Medycznego w Tarnopolu oraz 409 dziewczat z Tarnopola, zachodnia Ukraina. Jako metodę badawczą zastosowano Międzynarodowy Kwestionariusz Aktywności Fizycznej (IPAQ-L). Wzięto również pod uwagę wskaźniki BMI i samooceny aktywności fizycznej.

Wyniki. Badane studentki z Państwowego Uniwersytetu Medycznego w Tarnopolu i uczennice z Tarnopola (zachodnia Ukraina) wykazują wysoki poziom aktywności fizycznej. Większość badanych studentek $(71,1 \%)$ i uczennic $(59,4 \%)$ ma normalną masę ciała. Samoocena sprawności fizycznej uczennic była niższa, ale bardziej adekwatna niż studentek. Ponadto, zarówno uczennice, jak i studentki, które wskazywały na brak wolnego czasu, potrafiły go wykorzystać w bardziej rozsądny sposób niż te, które uważały, że mają go wystarczająco dużo lub zbyt mało.

Wnioski. Studentki uniwersytetu medycznego i uczennice $\mathrm{z}$ Tarnopola są w pełni świadome, że aktywność fizyczna jest ważna w ich życiu i że stanowi kluczowy czynnik w kształtowaniu zdrowego stylu życia.

Słowa kluczowe: aktywność fizyczna, IPAQ-L, BMI, samoocena, sprawność fizycznej, kobieta, student

Popovych D, Bergier J, Korda M, Klishch I, Sopel O, Tsybulskaya L. Evaluation of physical activity, body mass index and self-assessment of physical fitness in female students and pupils of Ternopil, western Ukraine. Health Problems of Civilization. 2017; 11(3): 163-172. doi: 10.5114/hpc.2017.70006.

Address for correspondence / Adres korespondencyjny: Dariya Popovych, I. Horbachevsky Ternopil State Medical University, m. Voli 1, Ternopil, 46001, Ukraine, e-mail: kozak@tdmu.edu.ua, phone: +380673511532

Copyright: (C) 2017 Pope John Paul II State School of Higher Education in Biała Podlaska, Dariya Popovych, Józef Bergier, Mykhaylo Korda, Ivan Klishch, Olha Sopel, Lyudmila Tsybulskaya. This is an Open Access journal, all articles are distributed under the terms of the Creative Commons Attribution-NonCommercial-ShareAlike 4.0 International (CC BY-NC-SA 4.0) License (http://creativecommons.org/licenses/by-nc-sa/4.0/), allowing third parties to copy and redistribute the material in any medium or format and to remix, transform, and build upon the material, provided the original work is properly cited and states its license. 


\section{Introduction}

Public health, and young people's in particular, is the most valuable and essential component of a country's social and economic prosperity. However, health gain and its maintenance in a population requires propagating a healthy lifestyle. The WHO states that a healthy living is one of the most important and most effective strategies in disease prevention.

A considerable number of Ukrainian adolescents have not yet developed a proper attitude to healthy leisure time: $99.5 \%$ of the teenagers spend much time working on a computer, while only $23.9 \%$ of them spend more than one hour outdoors and $20 \%$ do morning exercises.

The survey "The Youth of Ukraine 2015" conducted in 14-15-year-olds proved that 59\% of the participants engaged in athletics within the last 7 days, $26 \%$ did not play any sports or participate in other forms of intensive physical activity over the past year. $36 \%$ of the secondary school students demonstrated poor and 34\% - below an average level of physical development due to insufficient exercise, unhealthy lifestyle and pre-existing health issues [1,2].

Recent studies [3] and numerous literature publications try to determine the influence of social structure on the level of physical activity of children and youth worldwide [4,5,6,7]: in England [8], the Czech Republic [9], the United States [10], Finland [11], and Poland [12,13,14,15,16,17]. The downward trend in physical activity has already been observed in the provision of physical education classes at schools $[18,19]$.

The issue of the amount of physical activity in university students, as well as students of medical universities and schools, was the subject of several recent studies in South Asia, South Africa, Europe [20,21,22,23,24,25,26,27] and Ukraine [2]. The results show that the downward trend in college students' physical activity deserves more attention.

Over the past decade, the number of overweight and obese people has increased in most countries of the world, and in the developed countries it has become epidemic, which is significant socially [28,29,30,31,32], especially in the United States of America, Canada and Western Europe countries. For example, the highest rate of overweight and obese children in Europe is seen in Malta: 25.4\% and 7.9\% respectively. Younger generations are most affected, which leads to a number of unwanted consequences [33]. Chinese adolescents' self-rated level of insufficient physical activity amounted to $58.1 \%$. The overweight and obesity rates stood at $18.4 \%$, and $16.0 \%$ respectively [34]. BMI research presented that $13.2 \%$ of the boys and $14.5 \%$ of the girls in south-eastern Sweden were overweight [35]. In Ukraine, $15-16 \%$ of the school-age children were overweight and the number tends to rise $[28,36]$.

The low level of physical fitness (PF) is currently one of the key factors to a constant increase in the number of plump people in adults and young people [37]. Insufficient physical activity has a particularly negative effect on health condition in different population groups. Therefore, the problem of compensating for negative consequences of its deficit is an urgent pedagogical, social, medical and economic issue.

The aim of the following study was to evaluate the level of physical activity, determine the body mass index and analyse the self-rated physical activity in the female students of Ternopil State University and schoolgirls of the city of Ternopil.

\section{Material and methods}

The study involved 333(44.9\%) female students of Ternopil State Medical University and 409 (55.1\%) schoolgirls of Ternopil, western Ukraine. The age of the surveyed persons ranged from 17 to 19 in students and from 15 to 17 in pupils. They were asked to complete a questionnaire regarding physical and demographic activity as well as general physical activity. The International Physical Activity Questionnaire (IPAQ-L) [38] was used as the research method. A detailed International Physical Activity Questionnaire (IPAQ) evaluating physical activity in different domains, i.e. job-related one, housework, sport, and physical activity during leisure time, was completed. The BMI indicators and self-assessment of physical activity were also described. A statistical analysis was performed by means of STATISTICA v. 10. The arithmetic mean was calculated and the KruskalWallis and Mann-Whitney U tests were applied to estimate the general activity and step-by-step activities. The obtained findings are presented by means of qualitative variables as well as the Pearson's chi-squared test. The adopted level of statistical significance was $\mathrm{p}=0.05$.

\section{Results}

The results of the research demonstrated significantly high levels of total physical activity in female students (5590.2 MET $\times$ min/week) and in the schoolgirls (6881.1 MET $\times$ min/week). The highest level of physical activity in the female students was evidenced in the sports domain (1555.4 MET×min/week) and the lowest - at home 
1162.2 MET×min/week. The highest level of physical activity in the schoolgirls was again seen in sports (2665.3 MET×min/week) and the lowest - at home 1000.2 MET×min/week (Fig. 1).

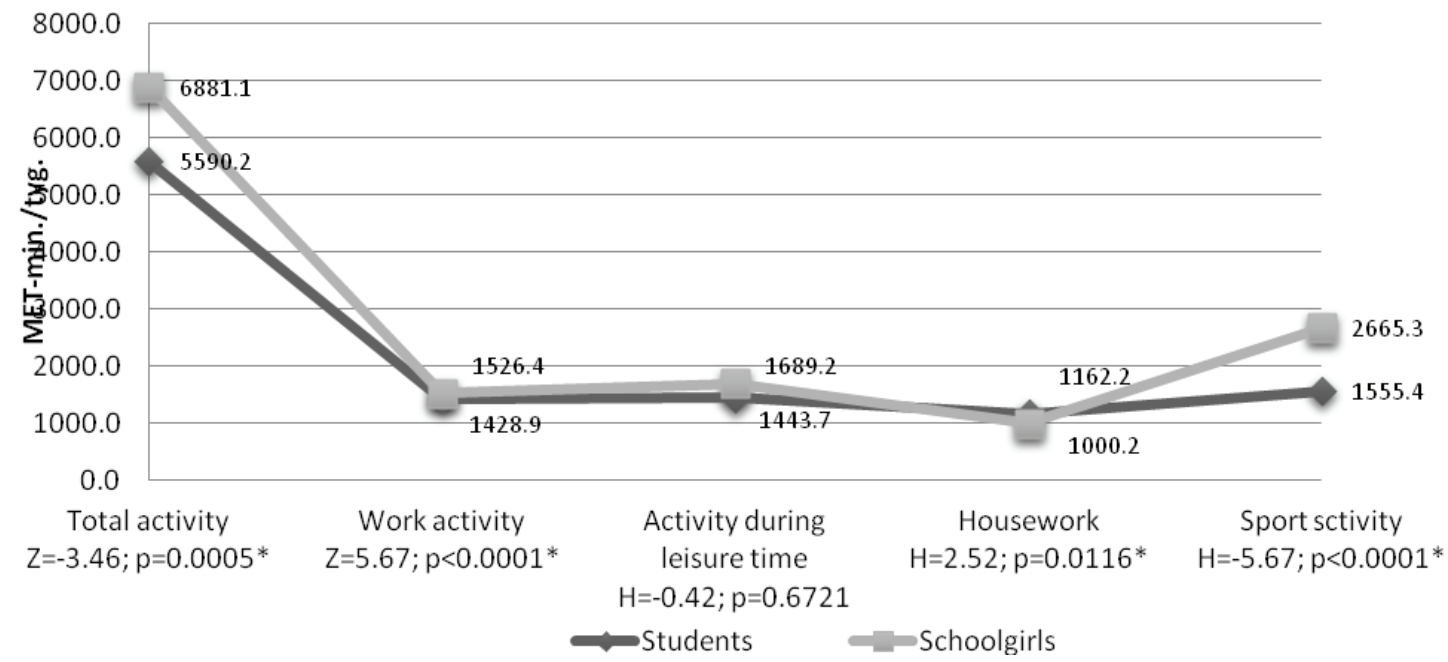

*significant differences at $<0.05$; Z- value of U Manna-Whitney test

Figure 1. Level and domains of physical activity in female students and schoolgirls

The BMI was calculated according to the results of the students' physical activity examinations. Following the recommendations by the WHO: the BMI ranging from 17.0 to $18.49 \mathrm{~kg} / \mathrm{m}^{2}$ is classified as underweight, $18.5-$ $24.99 \mathrm{~kg} / \mathrm{m}^{2}$ - as normal weight, and $25.0-29.99 \mathrm{~kg} / \mathrm{m}^{2}$ - as overweight. The BMI results showed that $19.9 \%$ of the female students were underweight, $71.1 \%$ of them were of normal weight and $6 \%$ were overweight. $38.9 \%$ of the schoolgirls were underweight, $54.4 \%$ - of normal weight and $1.7 \%$ were overweight. Thus, there were more overweight students when compared to pupils. In contrast, the percentage of those underweight was higher in the schoolchildren than in the students (Fig. 2).

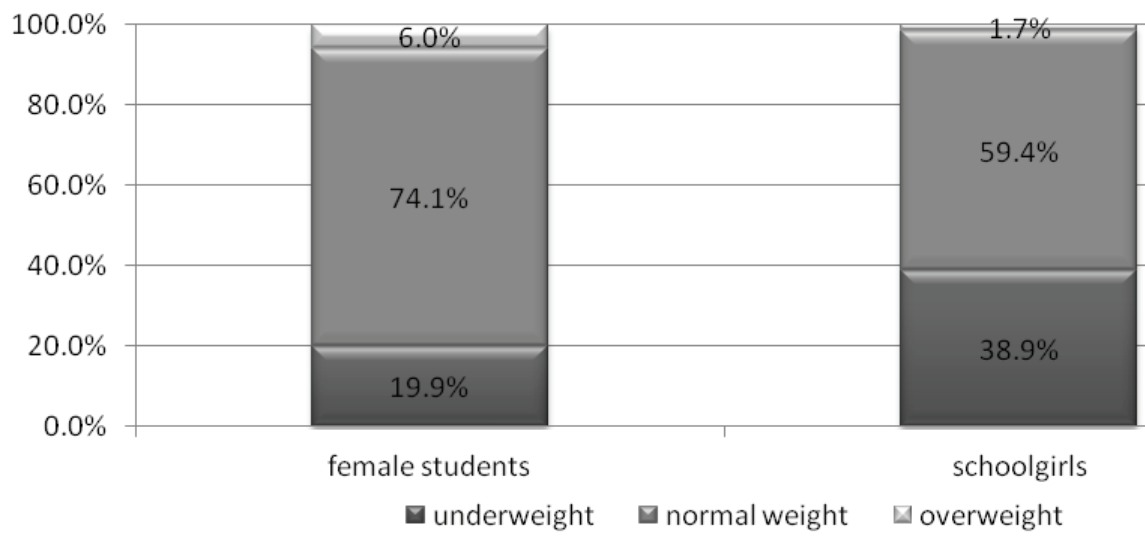

Value of Ghi square Person's Test: X2=37.12; $p<0.0001^{*}$

*significant differences at $<0.05$;

Figure 2. BMI of female students and schoolgirls

The results of the study into physical activity in general, including the body mass index in female students, showed that the highest level of PA (5757.6 MET×min/week) was demonstrated by those with normal body mass. The level of PA was slightly lower in those who are overweight and underweight (5399.6 and 5047.0 MET×min/ week, respectively), although these values were not significantly different. A similar tendency was observed while determining the level of PA in the domains of sport and recreation. The students with normal body weight demonstrated the highest level of PA in sports (1645.4 MET×min/week) and job-related activity (1495.7 MET $\times$ min/week). In the overweight women, the highest level of PA was observed in the domain of transportation - 1523.1 MET×min/week and at home - 1390.4 MET×min/week. In the underweight students, the highest level 
of PA was evidenced in transportation, i.e. 1336.4 MET×min/week. There were no significant differences in BMI in female students, in total PA and in other domains (Fig. 3).

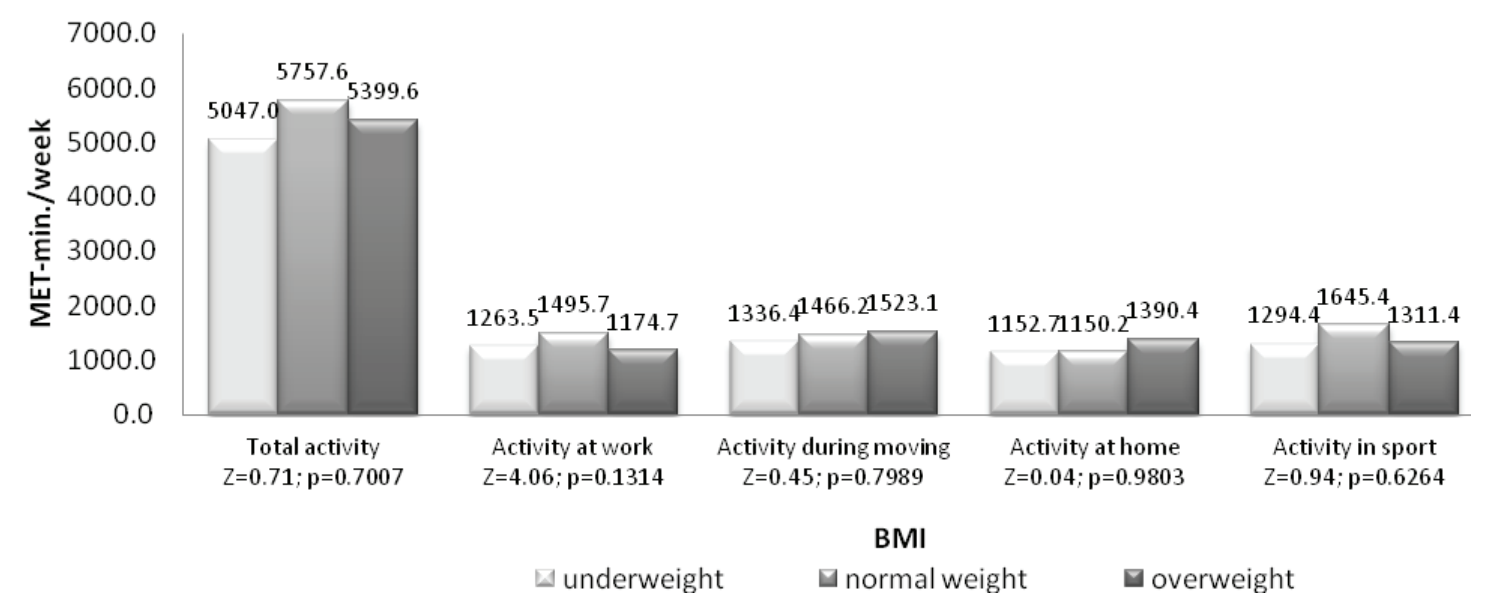

${ }^{*} \mathrm{H}$-value of Kruskal-Wallis test

Figure 3. Variation in general activity and its forms in students with regard to the BMI classification

When the BMI was taken into account, the results of the study of total physical activity showed a significant decrease $(\mathrm{N}=6.83, \mathrm{p}=0.03)$ in overweight schoolgirls' PA in general when compared to those who had normal weight or were underweight (2271.4,7013.5 and 6881.1 MET×min/week, respectively). At the same time, a similar tendency was observed in all other studied domains of PA: job-related activity, transportation, housework and sports. In the overweight schoolgirls, the lowest level of PA (631.1 MET×min/week) was observed in the sports domain. This value $(\mathrm{N}=7.63, \mathrm{p}=0.02)$ differed significantly from the indicators of PA level in sports in schoolgirls with normal weight or underweight ones. In the schoolgirls with normal body weight, the total level of PA and the level of PA in sports were the highest. In the underweight schoolgirls, the highest level of PA was seen in sports (Fig. 4).

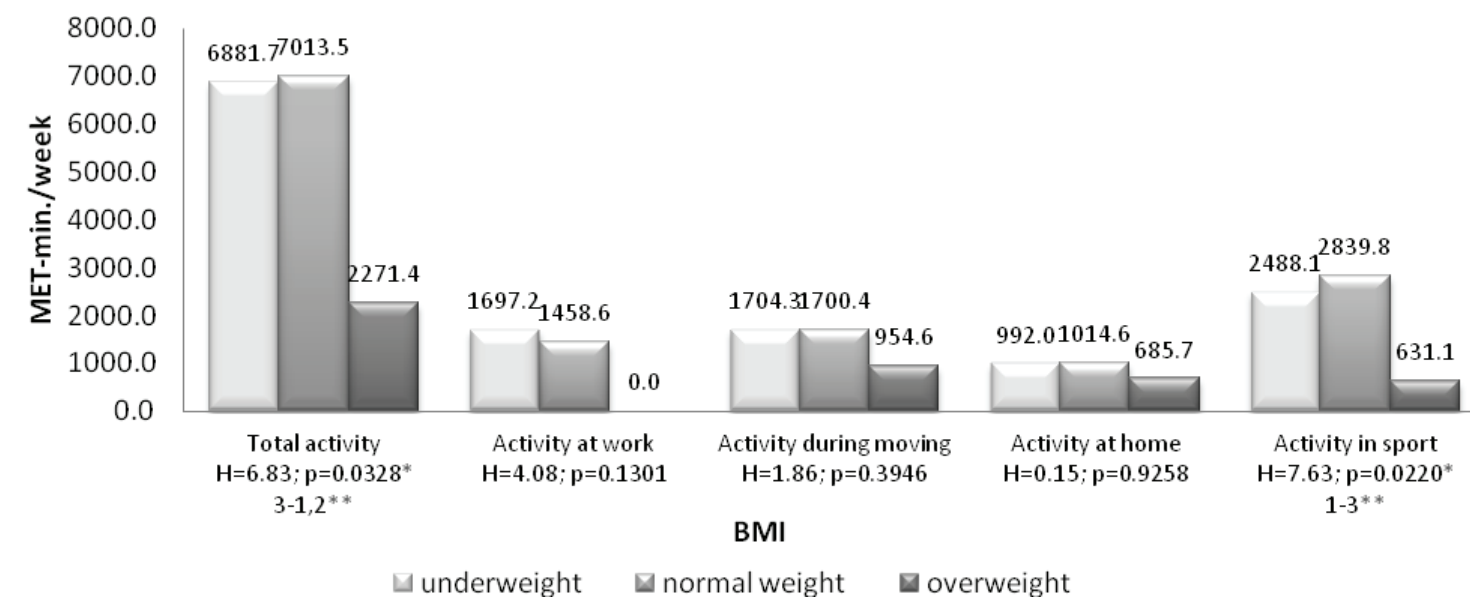

*significant differences at $<0.05$; H-value of Kruskal-Wallis test.

**Classification of BMI of the surveyed persons, in which there is a statistically significant variation

Figure 4. Variation in activity in general and its forms in schoolgirls with regard to the BMI values

In the study of the self-assessment of PA, the respondents were asked to evaluate their level of physical activity as low, medium or high. $15.9 \%$ of the interviewed students believed that their PA was low, $80.2 \%$ - average PA, and only $3.9 \%$ - high PA. $11.0 \%$ of the surveyed schoolgirls thought that their PA was low, $73.6 \%$ - average PA and $15.4 \%$ - high. Thus, the self-assessment of PA level in the schoolgirls was higher than that in the students. 4 times more schoolgirls than students estimated that their level of PA was high (Fig. 5). 


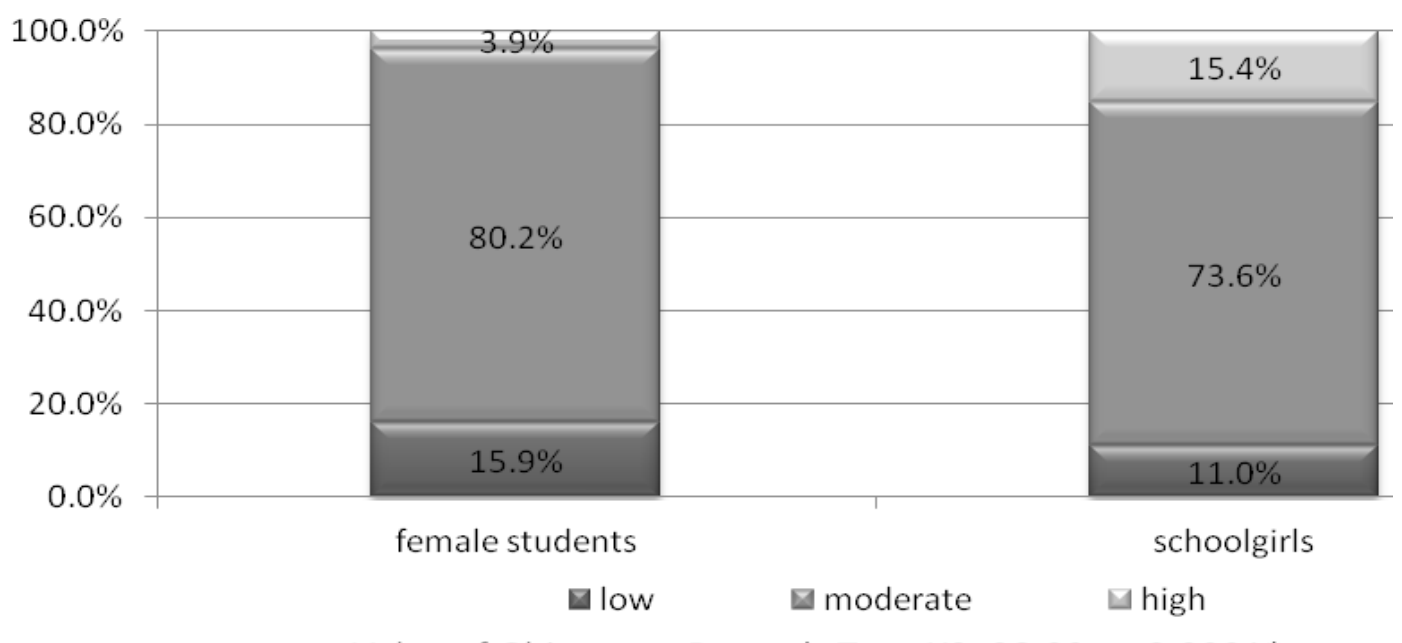

*significant differences at $<0.05$.

Figure 5. Physical fitness self-assessment in female students and pupils

The level of total PA and its domains in female students did not contain significantly important indicators and did not always coincide with the level of PA indicated in the female students' self-assessment of physical fitness. Thus, the level of total PA and the level of PA in sports in the students who considered it to be high was lower than that in the students who considered it to be low or moderate (Fig. 6).

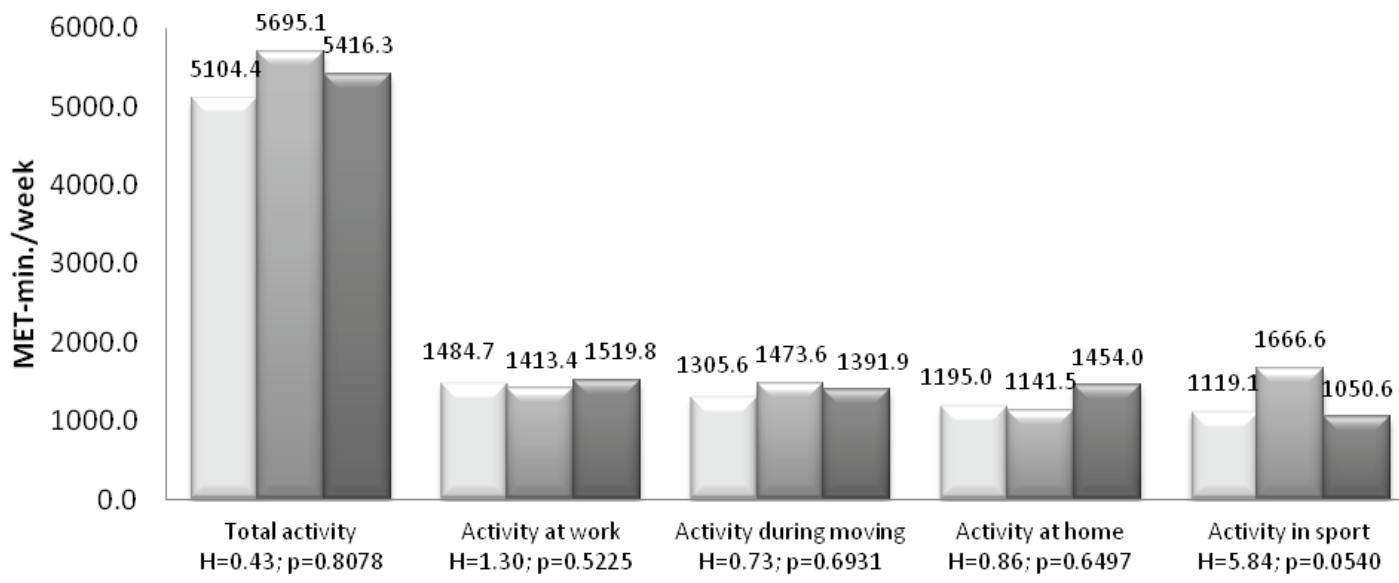

Self-assessment of physical fitness

$$
\square \text { low } \square \text { moderate } \square \text { high }
$$

${ }^{*} \mathrm{H}$-value of Kruskal-Wallis test.

Figure 6. Total activity and its forms in female students with regard to the self-assessment of physical fitness

The self-assessment of the PA level estimated by the surveyed schoolgirls was much lower but adequate. The level of total PA and the level of PA in sports fully corresponded to the level of total PA and the level of PA based on the schoolgirls' self-assessment of their physical fitness. Accordingly, in the schoolgirls who assessed the level of PA as high, the level of total PA was 8651.2 MET×min/week and in sports - 4404.5 MET×min/week; whereas in the schoolgirls who assessed their level of PA as low, the level of total PA was 5233.4 MET $\times$ min/week and in sports $-1246.6 \mathrm{MET} \times \mathrm{min} /$ week. These indicators were statistically significant. They did not correspond to the real values visible in the schoolgirls' self-assessment of the level of PA in job-related activity and at home (Fig. 7). 


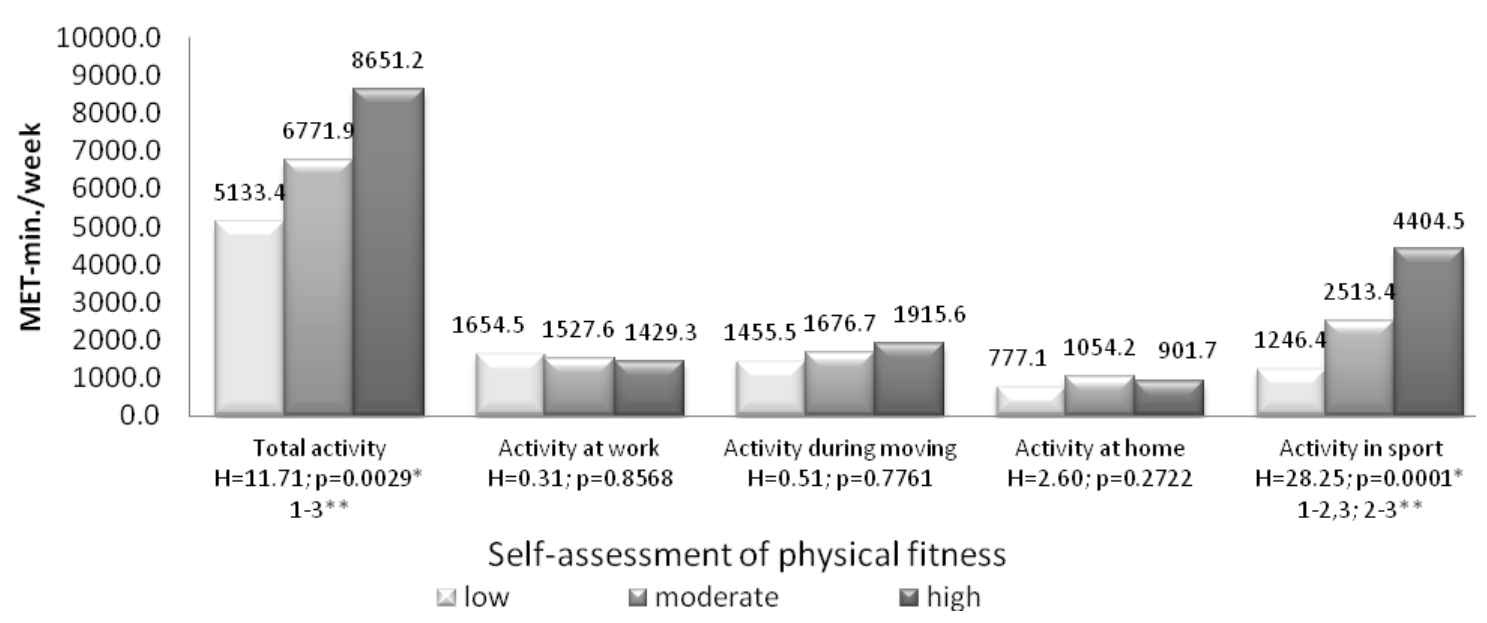

*significant differences at <0.05; H-value of Kruskal-Wallis test.

** self-assessment of the physical fitness in the respondents, in which there is a statistically significant variation

Figure 7. Total activity of schoolgirls and its forms with regard to the declared self-assessment of physical fitness

Further, the respondents were also surveyed on their leisure-time activity. Accordingly, $13.8 \%$ of the surveyed female students answered that they had no free time, $52.6 \%$ did not have enough leisure time, and $33.6 \%$ had enough free time. In the surveyed schoolgirls, $23.7 \%$ reported that they had no free time, $37.7 \%$ did not have enough free time and $38.6 \%$ claimed that they had enough.

The study findings on the level of PA, depending on the length of free time in the surveyed female students, proved that the highest level of total PA (6861.6 MET×min/week) in all forms of activities (at work, at home and in sports) was visible in those who thought that they did not have any free time. The female students who considered that they did not have enough free time demonstrated a high level of total PA (5751.6 MET×min/ week), although somewhat lower than indicated previously, also in all the other forms of PA (at work, at home and in sports). The female students who assumed that they had enough free time showed the lowest level of total PA (4815.9 MET $\times \mathrm{min} /$ week), also in all other forms of PA (job related, at home and in sports). The indicators in female students who did not have free time and those who had enough free time were statistically significant $(\mathrm{H}=7.20, \mathrm{p}=0.0273)$ (Fig. 8).

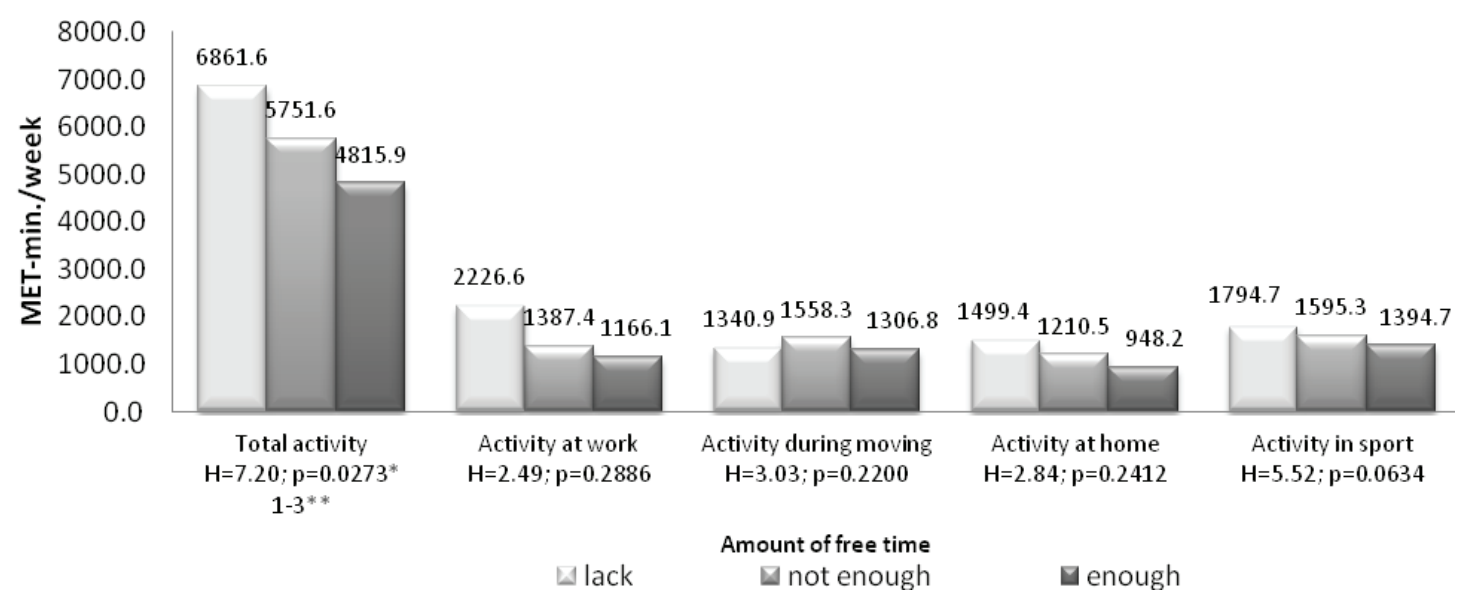

*significant differences at $<0.05$; H-value of Kruskal-Wallis test.

$* *$ the amount of free time, in which there is a statistically significant variation

Figure 8. Level of total physical activity in female students and its forms with regard to the amount of their free time

When the amount of their free time was considered, the results of the study of PA level in the surveyed schoolgirls showed that the highest value of total PA (7043.9 MET×min/week) and PA in sport (2901.2 MET×min/ week) was evidenced in those who believed that they had no free time. Just about the same levels of total PA and sports activity (6983.3 and 2767.9 MET×min/week respectively) were visible in the schoolgirls who believed 
that they had enough leisure time. The corresponding levels in the schoolgirls who said that they did not have enough free time were slightly lower (6673.7 and 2411.5 MET×min/week, respectively) (Fig. 9).

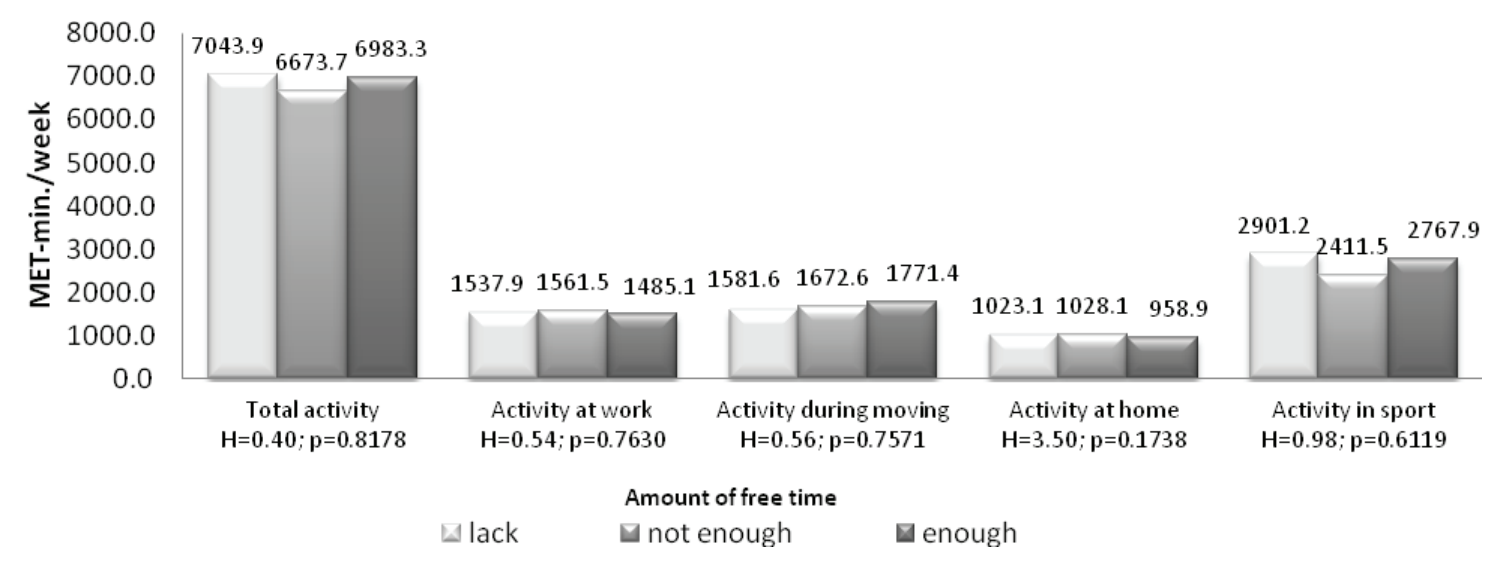

* H-value of Kruskal-Wallis test.

Figure 9. Level of total physical activity in the schoolgirls and its forms with regard to the amount of their free time.

\section{Discussion}

The results of the research showed that the level of total physical activity in female students (5590.2 MET×min/week) and in the pupils (6881.1 MET×min/week) was high.

Over the past decade, the number of overweight people and different types of obesity has increased in most countries of the world, and it has become epidemic and socially significant in the developed countries $[29,30,31,32]$.$] . In Ukraine, the rate of overweight children ranges from 15$ to $16 \%$ and currently tends to rise $[28,36,39]$. According to our research, the majority of the surveyed female students (71.1\%) and pupils (59.4\%) of Ternopil (Western Ukraine) have normal body weight, which results from the high level of total PA (5590.2 and 6881.1 MET×min/week respectively) and its forms. The results of our studies coincide with the ones obtained by other authors [40] and indicate that the number of female students with normal weight tends to increase. A proper day routine with regular exercise and a balanced diet decreases the risk of becoming overweight in people of all ages, especially in the young [28,31].

Currently, according to various data, the prevalence of the overweight among student youth amounts to $20 \%$ [41], and it becomes a significant issue. According to our research, $6 \%$ of the surveyed female students were overweight. The overweight growth is mainly caused by poor nutrition habits in the family (overeating), insufficient physical activity (hypodynamia) and stress [42]. Other authors [43] believe that the increased BMI is likely to be associated with malnutrition, lack of physical activity and sedentary lifestyle. It is established that students' lifestyle is determined by a very intensive educational process, which is mostly inactive, inappropriate diet and fast food, quick snacks with chips, candies, sweet drinks, and bad habits (smoking, alcohol). Obviously, such an unhealthy lifestyle of the present-day students contributes to a fast weight gain while at the university, which is confirmed by other authors [41,44].

According to our research, only $1.7 \%$ of the surveyed students were overweight. The value of the lowest level of total PA of the overweight schoolgirls was statistically significant $(\mathrm{H}=6.83, \mathrm{p}=0.03)$ when compared with the schoolgirls with normal weight or those underweight. In the overweight schoolgirls, the lowest level of PA (631.1 MET×min/week) was evidenced in the domain of sports. At present, the low level of PA is recognized as one of the main factors of a steady increase in the number of obese people in adults and young people [28,37].

$38.9 \%$ of the surveyed schoolgirls were underweight, and their level of total physical activity was high (6881.1 MET $\times \mathrm{min} /$ week), with the highest demonstrated in the domain of job-related activity (1697.2 MET×min/week) and in transportation (1704.3 MET×min/week) as well as a high PA level in sports (2488.1 MET×min/week). It can be assumed that a weight loss in these schoolgirls was related to malnutrition and high mental workload, because the respondents came from the graduating class and were about to start preparing for the admission to the university. Also, it was probably due to the great attention which the girls paid to their slender figures, which is confirmed by other authors [43].

According to our research, the surveyed schoolgirls' self-assessment of the level of PA was much lower and more adequate than that of the female students. The level of total PA and the level of PA in the sports domain fully corresponded to the level of total PA $(\mathrm{H}=11.71, \mathrm{p}=0.0029)$ and the level of $\mathrm{PA}(\mathrm{H}=28.25, \mathrm{p}=0.0001)$ visible in 
the schoolgirls' self-assessment of their physical fitness. According to other authors [42], high school students' self-assessment rate was quite high, despite the low level of physical activity.

As for the free time assessment of the respondents taking part in the survey, it was established that the number of female students and pupils having enough free time was the same. 1.74 times more schoolgirls than female students believed that they had no free time $\left(X^{2}=19.79, p<0.0001\right)$. The results of the study of the level of PA based on the amount of free time in the surveyed female students and pupils proved that those who believed that they had no free time demonstrated the highest level of general PA. The same can be said about other forms of PA (the job-related one, at home and in sports).

\section{Conclusions}

1. The youth of Ternopil: both female students and pupils, demonstrate a high level of physical activity (5590.2 and 6881.1 MET×min/week respectively).

2. Most of the surveyed female students and pupils had normal weight; however, $6 \%$ of the female students were overweight and $38.9 \%$ of the schoolgirls were underweight.

3. Self-assessment of physical fitness in schoolgirls was more adequate compared to the one in female students as they were more critical.

4. The female students and pupils who considered that they had no free time demonstrated the highest level of total PA, also in all other forms of PA. Thus, these individuals spent their free time more reasonably than those who considered they did not have enough of leisure time or had enough of it.

5. Accordingly, it can be said that female students of medical universities and female pupils of Ternopil understand how important physical activity is in their lives and that PA is a key factor to a healthy lifestyle.

\section{References:}

1. Kozak DV, Sopel OM, Tsybulskaya LS. Estimation of physical activity of student youth. Materials of the final LIX scientific-practical conference «Achievements of clinical and experimental medicine». June 15, 2016, Ternopil.

2. Popovych DV, Bergier J, Sopel OM, Tsybulska LS, Korda MM. Physical activity levels in female students of Ternopil State Medical University. International Journal of Medicine and Medical Research. 2016; 2(2): 37-41.

3. Dencikowska B, Dencikowski D, Dencikowska A. Uwarunkowania społeczne samooceny aktywności fizycznej chłopców. Lider. 2010; 3: 13-15.

4. Moore LL, Lombardi DA, White MJ, Campbell JL, Oliviera SA, Ellison RC. Influence of parents' physical activity levels on activity levels of young children. The Journal of Pediatries. 1991; 2: 215-219.

5. Shropshire J, Carroll B, Family Variables and Children's Physical Activity: Influence of Parental Exercise and Socio-Economic Status. Sport, Education and Society, 1997; 1: 95-116.

6. Prochaska JJ, Sallis JF, Long B. A physical activity screening measure for use with adolescents in primary care. Arch. Pediatr. Adolesc. Med. 2001; 155(5): 554-559.

7. Yang X, Telama R, Laakso L. Parents' Physical Activity, Socio-Economic Status and Education as Predictors of Physical Activity and Sport Among Children and Youth - a 12-year follow-up study. International Review for Sociology of Sport. 1996; 31(3): 273-294.

8. Amstrong N. European children are fit and active: fact or fiction? EU Conference: Young People's Lifestyles and Sedentariness. Essen, Germany; 2004.

9. Rycztesky A. Active lifestyles of young people - benefits and outcomes. EU Conference: Young People's Lifestyles and Sedentariness. Essen, Germany; 2004.

10. Elder J. Obesity in children: Lessons from American homes, schools and communities: European children are fit and active: fact or fiction? EU Conference: Young People's Lifestyles and Sedentariness. Essen, Germany; 2004.

11. Telama R, Naul R, Nupponen H, Rychtesky A, Vuolle P., editors. Physical Fitness, Sporting Lifestyle and Olympic Ideals: Cross-Cultural, Studies on Youth Sports in Europe. CSSPE Sport Science Studies vol. 11. Schorndorf: Verlag Karl Hofmann; 2002.

12. Charzewski J, Lewandowska J, Piechaczek H, Syta A, Łukaszewska L. Kontrasty społeczne rozwoju somatycznego i aktywności fizycznej dzieci 13 - 15-letnich. Studia i Monografie, Warszawa: AWF; 2003 (in Polish).

13. Woynarowska B, Mazur J. Zachowania zdrowotne i zdrowie młodzieży szkolnej w Polsce i innych krajach. Warszawa; 2000 (in Polish). 
14. Syta A. Społeczne uwarunkowania rozwoju i aktywności fizycznej dzieci w wieku od 10 do 15 lat. Rozprawa doktorska, Warszawa: AWF; 2005 (in Polish).

15. Dencikowska A. Social conditioning of motor activities of 13 - 15 year old boys from Rzeszów. In: Obodyński K, Cynarski W., editors. Regional Tourism versus European Integration and Globalization. Rzeszów: UR; 2005a, p. 154-161 (in Polish).

16. Charzewska J, Wajszczyk B, Chabros E, Rogalska-Niedźwiedź M. Aktywność fizyczna w Polsce w różnych grupach według wieku i płci. In: Jarosz M., editor. Otyłość, żywienie, aktywność fizyczna, zdrowie Polaków. Warszawa: Instytut Żywności Żywienia; 2006, p. 317-340 (in Polish).

17. Charzewski J. Aktywność sportowa Polaków. Warszawa: Resortowe Centrum Metodyczno-Szkoleniowe Kultury Fizycznej i Sportu; 1997 (in Polish).

18. Dencikowska A, Dencikowska B, Dencikowski D. Samoocena aktywności fizycznej a cechy somatyczne. LIDER. 2009; 216(1): 10-11 (in Polish).

19. Shani D, Nimbalkar A, Phatak A, Nimbalkar S. Training in dietary practices and physical activity to improve health among South Asian medical students. Advances in Preventive Medicine. 2014; doi: http:// dx.doiorg/10.1155/2014/610180.

20. Draper C, Basset S, Anniza de Villiers, Estelle V. Lambert, and the HAKSA Writing Group. Results From South Africa's 2014 Report Card on Physical Activity for Children and Youth. Journal of Physical Activity and Health. 2014; 11(Supp 1): 98-103.

21. Pengpid S, Peltzer K. Physical inactivity and associated factors among university students in South Africa. African Journal for Physical, Health Education, Recreation and Dance AJPHERD. 2013; 19(1): 143-53.

22. Bergier J, Kapka-Skrzypczak L, Bilinski P, Paprzycki P, Wojtyta A. Physical activity of Polish adolescents and young adults according to IPAQ: a population based study: Ann Agric Environ Med. 2012; 19(1): $109-15$.

23. Baar J, Romppel M, Igel D. Associations between the residential environment and physical activity in german college students and the role of self-efficacy as a mediator. Zeitschrift fur Gesundheitspsychotogie. 2014; 22(3): 118-128.

24. Pedisic Z, Rakovac M, Bennie J, Jurakic D, Bauman AE. Levels and correlates of domain-specific physical activity in university students: Cross-sectional findings from Croatia. Kinesiology. 2014; 46(1): 12-22.

25. Dąbrowska-Galas M, Plinta R, Dąbrowska J, Skrzypulec-Plinta V. Physical activity in students of the Medical University of Silesia in Poland. Phys Ther. 2013; Маг 93(3): 384-92.

26. Buchman BP, Sallis JF, Criqui MH, Oimsdale JE, Kaplan RM. Physical activity, physical fitness, and psychology characteristics of medical students. J Psychosom Res. 1991; 35: 197-208.

27. Dub M. Modern approaches to the physical rehabilitation of overweight and obesity in university. Marian Dub, Kseniya Melega, Young Sports Science of Ukraine: collection of scientific works on the field of physics. Education, sports and health of the person for the community. Ed. Yevhen Prystupa. 2012; 16(3): 87-94.

28. Ametov AS. Obesity - the epidemic of the XXI century. Ter. Archive. 2002; 10: 5-7.

29. Branca F, Nikogosian H, Lobstein T, editors. The problem of obesity in the WHO European Region and the strategy for its solution. Summary. World Health Organization; 2007.

30. Bagchi D, Preuss HG, editors. Obesity: epidemiology, pathophysiology, and prevention. Boca Baton: CRC Press, Taylor \& Francis Group; 2006.

31. Junger J, Niznikowska E, Bergier B, Fromel K, Salonna F, Acs P, et al. BMI indicator and self-assessment of physical activity of students in the visegrad countries. Health Problems of Civilization. 2016; 10(4): 14-25.

32. Hills AP, Andersen LB, Byrne NM. Physical activity and obesity in children. Br J Sports Med. 2011 Sep; 45(11): 866-70.

33. Wang H, Fu J, Lu Q, Tao F, Hao J.Physical activity, body mass index and mental health in Chinese adolescents: a population based study. J Sports Med Phys Fitness. 2014 Aug; 54(4): 518-25.

34. Raustorp A, Pangrazi RP, Ståhle A. Physical activity level and body mass index among schoolchildren in south-eastern Sweden. Acta Paediatr. 2004 Mar; 93(3): 400-4.

35. Miniyalova N. Social-genetic aspects of obesity. Pediatrics. 2001; 2: 83-87.

36. U.S. Department of Health and Human Services. Physical Activity and Health: A Report of the Surgeon General. Atlanta; 1996.

37. Booth ML. Assessment of physical activity: An International Perspective. Res. Quart. Exerc. Sport. 2000; 71: 114-120.

38. Yevstratov P, Bilyk L, Zorij Y. Peculiarities of Indexes of Body Mass of Girls-Students of the First Course of Humanitarian Specialities of Chernivtsi National University. Physical education, sports and health culture in modern society: a collection of scientific works. 2012; 3 (19): 200-205. 
39. Wang H, Fu J, Lu Q, Tao F, Hao J. Physical activity, body mass index and mental health in Chinese adolescents: a population based study. J Sports Med Phys Fitness. 2014 Aug; 54(4): 518-25.

40. Blavat OZ. Swimming as a method of depriving students of obesity Special medical department in the conditions of the university. Pedagogy, Psychology and Medical-biological Problems of Physical Exhaust and Sports. 2010; 1: 17-25.

41. Rubalko P, Skachedub N, Yaroshyk M. Managing high-school pupils' physical activity. Young Sport Science of Ukraine. 2013; 2: 176-180.

42. Omelchenko T. Body mass index as a criterion for pre-morbid diagnosis in the prevention of overweight in students aged 18-22 years. Theory and Methods of Physical Education and Sports. 2016; 1: 49-52.

43. Griban G. Analysis of the health of students of higher educational institutions. Sports Bulletin of the Dnieper: Scientific and Theoretical Journal. 2004; 7: 130-132. 